Maurice A. Deane School of Law at Hofstra University Scholarly Commons at Hofstra Law

Hofstra Law Faculty Scholarship

2003

\title{
Restorative Justice and the Jewish Question
}

Daniel J.H. Greenwood

Maurice A. Deane School of Law at Hofstra Univsersity

Follow this and additional works at: https://scholarlycommons.law.hofstra.edu/faculty_scholarship

\section{Recommended Citation}

Daniel J.H. Greenwood, Restorative Justice and the Jewish Question, 2003 Utah L. Rev 533 (2003)

Available at: https://scholarlycommons.law.hofstra.edu/faculty_scholarship/318

This Article is brought to you for free and open access by Scholarly Commons at Hofstra Law. It has been accepted for inclusion in Hofstra Law Faculty Scholarship by an authorized administrator of Scholarly Commons at Hofstra Law. For more information, please contact lawcls@hofstra.edu. 


\title{
Restorative Justice and the Jewish Question*
}

\author{
Daniel J.H. Greenwood ${ }^{*}$
}

\section{INTRODUCTION}

The language of some sectors of the restorative justice movement clearly reflect roots in Christian religious thinking: it is the language of reformation, repentance, and revival. "Crime is an opportunity to prevent greater evils, to confront crime with a grace that transforms human lives to paths of love and giving." This Article was prepared for a panel that was asked to reflect on the significance of that religious origin and the strong religious element in many of the actual programs.

Great caution is necessary in using the language and concepts of particular religious traditions in designing a criminal justice program for a pluralist society. An effective criminal law works mainly by teaching. But teaching will be most effective, and perhaps only can be effective, if it is done in a common language. We Americans are heirs to many religions with distinctive and powerful sets of traditions, myths, and imagery. The language of our varying religions is not where we are likely to find the common understandings of right and wrong that must permeate successful and defensible criminal law. Restorative justice will be more effective if it is able to transcend the religious and specifically Christian concepts that have inspired some of its proponents.

While the particular languages of our differing religious traditions do not seem to me to be good bases for a public criminal law, they are useful for considering familiar issues in an unfamiliar light. I therefore offer a reading of a set of unfamiliar texts from the Talmud, one of the foundational texts of the Jewish tradition, to make two basic points about criminal law with some

(C) 2002 Daniel J.H. Greenwood. All rights reserved.

"Professor of Law, S.J. Quinney College of Law at the University of Utah. This Article was prepared for the Utah Restorative Justice Conference and made possible by the generous support of the S.J. Quinney College of Law Research Stipend Program. I am deeply grateful for research assistance provided by the College of Law library, for the support of my colleagues, and for the comments of Leslie Francis, Karen Engle, Erik Luna, and conference participants.

'John Braithwaite, Restorative Justice: Assessing Optimistic and Pessimistic Accounts, 25 CRIME \& JUST. 1, 2 (1999) (emphasis added). For an account of restorative justice as a specifically Christian movement, see Charles W. Colson, Truth, Justice, Peace: The Foundations of Restorative Justice, 10 REGENT U. L. REV. 1 (1998). 
applicability to the restorative justice debate. ${ }^{2}$ At the same time, their language and structure should illustrate how disparate our traditions are.

First, criminal law should have a limited, nontranscendental goal. Torah law, like some of the more religious manifestations of restorative justice, claims divine authority and aims at ultimate justice-but the Jewish texts demonstrate that consistent working out of that view leads to the conclusion that ideal criminal law is impossible for humans to administer. In our democratic state, our goals should be less lofty; but the Jewish law experience suggests, I argue, that we nonetheless ought to be wary of the hubris inherent in any criminal law. Judges necessarily play God (in Biblical Hebrew, the word elohim can mean either one); we should try to arrange matters so that they do so as little as possible. The religious goals of bringing redemption, restoring true justice to the world, or even "transforming human lives to paths of love and giving" are best left to other institutions. The Jewish law texts are thus a warning against the restorative justice movement's more messianic aspirations to "restore" and heal the world. Merely reducing crime is a sufficiently difficult goal.

Second, the Jewish law debate provides an alternative justification for the restorative justice emphasis on mediation and mutual agreement. Criminal law, in the end, must be defended on empirical grounds: primarily that it works to reduce crime and secondarily that it mitigates the pain caused by crime it fails to prevent. While that discussion is largely an empirical one to which law professors are poorly qualified to contribute, I do suggest that the historical experience of Jewish law's attempts to substitute mediation for coercion offer qualified support for the community-based mediation techniques of some versions of restorative justice. Mediation and compromise can be based in the spirit of humility that is appropriate when humans try to judge things that, in an ideal world, would not be judged by those of only human abilities.

In short, this Article attempts to demonstrate the futility of particularist, religious-law based criminal law, using itself the language and traditions of a particular religious law system. If it succeeds, it will simultaneously illustrate the

${ }^{2}$ For a concise description of the Jewish legal tradition and the sources it employs, see Suzanne Last Stone, In Pursuit of the Counter-Text: The Turn to the Jewish Legal Model in Contemporary American Legal Theory, 106 HARV. L. REV. 813, $816 \mathrm{n} .13$ (1993). The ancient Jewish law sources are extremely terse and often ambiguous; as a result, translations often differ radically. My translations of Jewish law sources in this Article reflect my own imperfect understandings; unless otherwise indicated, they rely on but may vary from the cited standard translations where I am emphasizing a different reading.

The Torah, as I use the word in this Article, refers to the first five books of the Hebrew Bible. The words are identical to the first five books of the Christian Old Testament (within the vagaries of translation) but is a significantly different book. Cf. Jorge Luis Borges, Pierre Menard, Author of Don Quixote, in FICCIONES (1962) (describing book with same words as, but different meaning and significance than, Don Quixote). The word "torah" can also more generally refer to the entire Hebrew Bible, or to Jewish law in general. 
universality of the underlying concerns and the particularity of the language in which we debate them.

\section{GOD AND CRIME}

Some proponents of the restorative justice movement base their claims on the notion that belief in God can or is necessary to solve the problems of the world. Charles Colson, for example, in an article subtitled The Foundations of Restorative Justice, contends that crime is the result of loss of belief in "objective truth," which he seems to equate with belief in God: "As Dostoyevsky noted: If there is no God, everything is permissible. Crime becomes inevitable." This strikes me as arrant, and arrogant, nonsense. No human could exist if "everything is permissible"--human life is possible only with the rather extreme cooperation that makes childrearing and food production possible. Plato is more sensible on the subject: "Even a gang of thieves will subscribe to justice among themselves."

To be sure, belief in God helps some people act morally, but good and evil are done by religious and nonreligious alike. For every person who acts morally out of their religious beliefs, others act morally with purely secular selfconceptions: the civil rights movement was led (and opposed) by church leaders and fought in the language of the Bible, but it was staffed with secular kids from the colleges far more than with volunteers from white churches; the French Resistance drew its strength from the Enlightenment, not the Church. Not only is belief in God not necessary for moral action, it is not sufficient. For all the individuals who find in their religions the strength to struggle for good and decency, others find in God the explanation that permits them to, for example, defend segregation, burn their neighbors alive, or ram jets into large buildings. Isaiah was not the first or the last to notice that some people find the practice of religious ritual a substitute for, rather than a goad towards, the requirements of justice: "Is this the fast I have chosen? ... [R]ather ... let the oppressed go free, break every yoke, ... give your bread to the hungry."

${ }^{3}$ Colson, supra note 1 , at 3 (citations omitted). Yes, this is Chuck Colson of Watergate fame. Dostoyevsky, unlike Colson, is quite aware of the complexity of the problem. But 1 leave a discussion of the theology of Crime and Punishment and The Brothers Karamazov to another day.

${ }^{4}$ Plato, Republic 351c, quoted in R. Nissim Gerondi (Ran), Derashot, Sermon 11, translated in 1 THE JEWISH POLITICAL TRADITION 156 (Michael Walzer et al. eds., 2000).

${ }^{5}$ Isaiah 58:5-8 (denouncing those who observe ritual requirements of religion rather than justice, read during Yom Kippur services). The trope is so central a part of our culture, via Jesus' denunciation of the fundamentalists of his age, that the very terms "hypocrite" and "sanctimonious" have as their primary referents believers and practitioners of religion who do not follow the basic codes of decent conduct towards humans. 
Religions instead offer languages and sets of stories with which to approach . the difficult problems of a decent life. ${ }^{6}$ It is no accident that the Nazis took as their paradigmatic enemy the "Christ killers" of their traditional religion, or that the Communists built entire movements on hopes for messianic salvation, or, on the other hand, that many of the heroes of the various struggles against evil have used religious imagery or have been religiously inspired. Rather than solving the problems of communal life, our religions simply reflect them. Religions and Godtalk generally offer us tools and languages for expressing our ideals, hatreds, aspirations, fears, and feelings: rarely, it seems to me, do they make good people bad or the reverse. ${ }^{?}$

My own Jewish tradition is typical in this respect. It is founded not only on a universalist conception of the brotherhood of humankind but also on perhaps the oldest surviving stories, or at least the oldest surviving stories widely read in this country, of tribal massacres mandated by God. ${ }^{8}$ But in its post-Joshua form it takes a somewhat different view on the relationship of God and morality.

Judaism is defined in relation to a set of norms, rather than a set of beliefs or dogmas. ${ }^{9}$ In earlier work, I have described a talmudic debate about the role of God

${ }^{6}$ See Robert M. Cover, The Supreme Court, 1982 Term-Foreword: Nomos and Narrative, 97 HARV. L. REV. 4, 4-5 (1983).

${ }^{7}$ Bad people (and good people) often seek to wrap themselves in religious imagery, sometimes so successfully that it is hard to separate the one from the other. But it is hard to find an instance where the causality clearly runs from good religion to good people or vice versa. Plenty of people have killed in the name of their religion's ideal of peace and brotherhood.

${ }^{8}$ Compare Genesis 1:27 (teaching basic equality and brotherhood by story of all humankind descended from one set of parents), and Exodus 20:13 (barring murder), with Deuteronomy 25:19 (cursing Amalek, requiring that entire tribe be blotted out), and id. 20:16-17 (requiring that seven nations that inhabited Canaan be exterminated). See generally MISHNAH, Sanhedrin 4:5, translated in JACOB NEUSNER, THE MISHNAH: A NEW TRANSLATION 591 (1988) (explaining story of Adam's creation as teaching that whoever kills single human being has committed crime similar to destroying entire world, for if Adam had been killed, so would all his descendants); 2 MAIMONIDES, The COMmandments 269 (Charles B. Chavel trans., 1967) [hereinafter MaIMONIDES, COMMANDMENTS] (listing bar on killing human being as Negative Commandment 289); 1 Maimonides, Commandments, supra, at 200, 202 (listing Positive Commandment 187: to exterminate the seven nations; and 188: to exterminate all seed of Amalek); MAIMONIDES, MISHNEH TORAH, Kings 1:1, translated in THE CODE OF MAIMONIDES (MishneH TORAH), BOOK 14: THE BOOK OF JUDGES 207 (Abraham M. Hershman trans., Yale Judaica Series No. 3, 1949) [hereinafter YALE JUDAICA SERIES] (stating that commandment to destroy seed of Amalek is one of three to be carried out upon entry into the Land).

"In relation to" because some of the behavioral norms are controversial and others may be observed in the breach or even by breaching them. A High Reform Jewish man who deliberately attends synagogue bareheaded to act out his rejection of halacha (Jewish law) is still acting in relation to the halachic rule that his head must be covered so long as he has not simply forgotten the norm. Similarly, Rabbinic Jewish law often preserves biblical rules by reversing, modifying, criticizing, or interpreting them in ways that seem radically nonobvious. The distinctive demand of the tradition is that it not be forgotten even if it is not observed (or observable) in any simplistic way. 
in setting the norms by which humans must live: the early Rabbis already understood that law is a problem for humans, not for Heaven. Or, as they put it, quoting Deuteronomy 30:12: "It is not in Heaven, that you should say, 'Who will go up to Heaven and bring it to us, so that we can hear it and do it." Rather, the law has been given by God-which means that it is here and ours and for us to make it work. Law, even divine law, is a project for humans. ${ }^{10}$

This tradition of human responsibility for human actions is most pronounced in the Jewish law of crimes. Early on, the Jewish tradition was deeply suspicious of the very concept of criminal law, not of the notion that there is a difference between right and wrong or that it is fairly easy to tell the difference in most cases. Rather, there was deep skepticism about the possibility and likelihood of human justice. Criminal law, as we shall see, seemed too important and dangerous to be left to humans.

\section{A. Divine Law and the Demands of Absolute Justice: A Law To Live By}

To understand the talmudic view, however, we must begin earlier. The Torah (mainly in Leviticus) explicitly includes a significant part of a criminal code, listing several dozen crimes that carry the death penalty, generally specifying which of the accepted methods-principally strangulation or stoning ${ }^{11}$ - was to

${ }^{10}$ See Daniel J.H. Greenwood, Akhnai, 1997 UTAH L. REV. 309, 309-58 (analyzing "'not in Heaven" debate); Daniel J.H. Greenwood, Beyond Dworkin's Dominions: Investments, Memberships, the Tree of Life, and the Abortion Question, 72 TEX. L. REV. 559, 612-24 (1994) [hereinafter Greenwood, Dworkin's Dominions] (reading biblical account of tree of knowledge to make argument about nature of human responsibility).

${ }^{11}$ See MISHNAH, Sanhedrin 7:1, translated in NEUSNER, supra note 8, at 595-96 (indicating that court ordered execution by stoning, burning, decapitation, or strangulation). 
be imposed. ${ }^{12}$ Other crimes are punished more mysteriously—by cutting off, understood later to mean a premature (natural) death. ${ }^{13}$

By the time of the Mishnah at the beginning of the Christian era, the biblical code was understood to include at least eighteen crimes punishable by stoning to death, ${ }^{14}$ as well as others by burning, ${ }^{15}$ decapitation, ${ }^{16}$ and strangulation. ${ }^{17}$ Maimonides, writing a millennium later, counts thirty-six crimes for which the Torah decrees a punishment of death. ${ }^{18}$ It is a drastic criminal law, then, requiring drastic punishments. ${ }^{19}$

${ }^{12}$ See, e.g., Exodus 21:12, 21:15-17, 21:29, 22:18 (listing crimes-including murder, enslavement, hitting or cursing parents, allowing known dangerous animal to kill someone, and witchcraft-for which criminal "shall surely die"); id. 22:18 ("[A] witch shall not live."); Leviticus 20:10-16 (indicating same penalty for various sexual acts, including adultery, various types of incest, man who beds another man in manner of woman, and bestiality). Note that the Hebrew original (literally, "die shall die"), unlike the King James translation, does not necessarily suggest that the criminal shall die by human hands. See, e.g., MiSHNAH, Sanhedrin 9:6, translated in NEUSNER, supra note 8, at 604 (describing debate regarding whether particular crime is punished by court-ordered strangling or only by Heaven); cf. Greenwood, Dworkin's Dominions, supra note 10, at 613-14 (discussing ZOHAR, Bereshith 57 and arguing that when God told Adam that he would die if he ate of tree of knowledge, He meant that Adam would become mortal). In other places the penalty is clearly meant to be carried out by humans. See, e.g., Deuteronomy 17:2 (decreeing death by stoning for proven idolatry); id. 21:18-21 (same, for stubborn and rebellious son); id. 22:21 (same, for bride who had premarital sex); id. 22:23 (same, for rape within city or both parties to adultery).

${ }^{13}$ For examples of crimes punished by cutting off, see Leviticus 18:29 (decreeing cutting off as penalty for committing abominations); id. 19:7 (same, for eating shlemim sacrifice after second day); id. 20:18 (same, for man having sex with woman during her period); Numbers 9:13 (same, for failing to observe Passover).

${ }^{14}$ MISHNAH, Sanhedrin 7:4, translated in NEUSNER, supra note 8, at 596-97 (listing eighteen offenses, including saying divine Name, profaning Sabbath, cursing father and mother using divine Name, being stubborn and rebellious son, being sorcerer, idolater, or soothsayer, and various sexual offenses).

${ }^{15}$ Id. 9:1, translated in NEUSNER, supra note 8, at 602 (listing two sexual offenses from Leviticus 18:17, 20:14, 21:9).

${ }^{16} / d$. (listing certain types of murderers as well as townsfolk of apostate town).

${ }^{17}$ Id. 9:6, translated in NEUSNER, supra note 8, at 604 (discussing execution by strangulation).

${ }^{18}$ MAIMONIDES, MishNeH TORAH, Sanhedrin 15:10, translated in 3 YALE JUDAICA SERIES, supra note 8, at 44 (listing eighteen crimes punishable by stoning); id. at Sanhedrin 15:11, translated in YALE JUDAICA SERIES, supra note 8, at 44 (listing ten crimes punishable by burning); id. at Sanhedrin 15:12, translated in YALE JUDAICA SERIES, supra note 8, at 44 (listing two crimes punishable by decapitation); id. at Sanhedrin 15:13, translated in Y ALE JUDAICA SERIES, supra note 8 , at 44 (listing six crimes punishable by strangulation).

${ }^{19}$ There is some evidence that in practice during the biblical period, the families of the victim and the criminal negotiated a settlement in lieu of the Torah law punishment. Thus, Josephus's discussion of the "eye for an eye" rule understands it as a background rule ordinarily not applied. See Flavius Josephus, 4 ANTIQUITIES OF THE JEWS 8.35.280, translated in WILliam WhiSTON, THE WORKS OF JOSEPHUS COMPLETE AND UNABRIDGED 122 (1988) ("He who maims a man shall undergo the same, being deprived of that limb whereof he deprived the other, unless indeed the maimed man be willing to accept money; for the law empowers the victim himself to assess the 
As to criminal procedure, however, the Torah is much more elusive. ${ }^{20}$ The full explanation of biblical criminal procedure appears only in Tractate Sanhedrin of the Talmud. For our purposes, the talmudic discussion can be summarized relatively briefly. The Bible states that no one is to be convicted except upon the testimony of two witnesses. ${ }^{21}$ The Talmud demonstrates that the ordinary background rules require that those witnesses be eyewitnesses ${ }^{22}$ that they be reliable (even after testing, they must not contradict themselves in any way), ${ }^{23}$ and God-fearing (on something like Dostoyevsky's rationale), so they must be Sabbath observant, kosher keeping, adult males. As eyewitnesses they must be able to testify not only to the physical action but the motive-not every homicide, after all, is a murder - and so they must be able to swear that they themselves warned the criminal that what he was about to do was a capitai crime and that he responded that he was aware of that and intended to commit the crime precisely because it was a crime. Circumstantial evidence was insufficient to support a conviction: the judge instructed, "Perhaps this is what you saw: that one was running after his fellow into a ruin, you ran after him and found him sword in hand and blood dripping, while the murdered man was writhing. If this is what you saw, you saw nothing."24

damage that has befallen him and makes this concession, unless he would show himself too severe."). As discussed below, the Talmud also encourages compromise in lieu of the biblical law but, unlike Josephus, does not seem to accept the possibility of a victim who "would show himself too severe"; an eye for an eye is held only to refer to monetary compensation, and courts are effectively barred from applying the Torah punishments. BABYLONIAN TALMUD, Bava Kama 84a-b, translated in THE BABYLONIAN TALMUD (R. Dr. I. Epstein ed. \& trans., 1988) [hereinafter SONCINO].

${ }^{20}$ The Torah makes clear that some procedure is necessary prior to human punishment but does not set out the full details. See, e.g., Deuteronomy 13:15 (specifying requirements of diligent inquiry, cross examination, and truth); id. 17:6 (requiring two witnesses).

${ }^{21} I d$. 17:6, 19:15 (setting out two-witness requirement).

${ }^{22}$ BABYLONIAN TALMUD, Sanhedrin 37b, translated in 17 AdIN STEINSALTZ, THE TALMUD: THE STEINSALTZ EDITION 69-75 (R. Israel V. Berman ed. \& trans., 1999) (barring circumstantial evidence); MAIMONIDES, MISHNEH TORAH, Sanhedrin 16:4, 20:1, translated in YALE JUDAICA SERIES, supra note 8 , at 45,60 (same).

${ }^{23}$ MISHNAH, Sanhedrin 4:5, 5:1-4, translated in NEUSNER, supra note 8, at 591-93 (describing necessity for extended examination of witnesses and statements that are disqualifying); MAIMONIDES, MISHNEH TORAH, Sanhedrin 12:2, 16:4, translated in YALE JUDAICA SERIES, supra note 8, at 34, 45 (specifying prior warning requirement); see also TOSEFTA, Sanhedrin 10:11-11:15 (similar).

${ }^{24}$ BABYLONIAN TALMUd, Sanhedrin $37 \mathrm{~b}$, translated in 17 STEINSALTZ, supra note 22 , at $69-75$. 
Similarly, confessions were inadmissible (and a fortiori, I suppose, plea bargaining, which involves even more suspect confessions): perhaps the confessor wished to commit suicide or was mentally disturbed..$^{25}$

Now, for a human court to consciously decide to kill a human is perilously close to murder. Accordingly, the text restricts the courts that may impose the death penalty. Only a great Sanhedrin, sitting in the Chamber of Hewn Stone at the Temple, ${ }^{26}$ composed of twenty-three or seventy-one ${ }^{27}$ ordained ${ }^{28}$ judges, each of whom spoke seventy languages, had children to teach them sympathy, and was a fine enough lawyer to be able to prove that a seemingly straightforward biblical text enacts a law opposite of what it is known to mean, ${ }^{29}$ could impose such a penalty.

Moreover, so as to assure that each judge considered the case fully (and perhaps to limit the effects of incompetent lawyering), each judge was required

${ }^{25}$ See MAIMONIDES, MishneH TORAH, Sanhedrin 18:6, translated in YALE JUdAICA SERIES, supra note 8, at 52 (providing this justification of rule). The Talmud thus takes a view of confessions opposite that found in classic civil law, which saw confession as the goal of every criminal procedure. Moreover, the talmudic view is quite different from the modern American suspicion of confession set out in Miranda v. Arizona, 384 U.S. 436 (1966), and its progeny. The American rule is based primarily on autonomy notions-specifically, the fear that law enforcement agents may coerce defendants into confessing. It has not been understood to require searching inquiry into the truth value of confessions that are the result of contract-like bargains even when the government offers quite attractive terms. In contrast, Maimonides's justification for the talmudic rule appears to be based primarily on truth concerns rather than autonomy: the Sanhedrin rule rejects confessions regardless of the circumstances under which they are given for fear not only of governmental coercion but also of psychological disorders, social pressure and expectations, or even simple mistakes of fact or law that might lead defendants to believe either that they ought to confess or that they are in fact guilty.

${ }^{26}$ Deuteronomy 17:10 (requiring capital court to sit in "the place that Adonai chooses," understood to be Chamber of Hewn Stone at Temple); BabYLONIAN TALMUD, Sanhedrin 52b, translated in 18 STEINSALTZ, supra note 22, at 42-50 (allowing no executions after destruction of Temple and ruling that death penalty could only be decreed while Temple was standing).

${ }^{27}$ MISHNAH, Sanhedrin 1:4, translated in NEUSNER, supra note 8, at 584.

${ }^{28}$ Ordination involved the laying on of hands by an ordained judge in a direct sequence back to the investiture of Joshua in Numbers 27:23. See, e.g., MAIMONIDES, MISHNEH TORAH, Sanhedrin 4:1, translated in YALE JUDAICA SERIES, supra note 8, at 13 (describing requirement).

${ }^{29}$ BABYLONIAN TALMUD, Sanhedrin 17a, translated in 15 STEINSALTZ, supra note 22 , at 179-87 (listing qualifications for sitting on Sanhedrin, including height, wisdom, good looks, age, knowledge of magic so as not to be fooled by magicians, knowledge of seventy languages so that no translator is needed, and ability to prove sheretz (swarming creature) pure based on Torah despite Leviticus 11:29-39, which states that it is impure). This listing of seemingly impossible qualifications is punctuated by the boast of one of the leading rabbis of the age, Rav, that he could meet the requirement of proving that a sheretz is clean and the anonymous editor's quick puncturing of the attempt: do not think that this is a trivial requirement. See also MAIMONIDES, MISHNEH TORAH, Sanhedrin 2:1, 2:3, 2:6-7, translated in YALE JUDAICA SERIES, supra note 8, at 7-8 (listing somewhat different set of qualifications, including understanding of major branches of knowledge, not being old or eunuch "because these have cruel streaks," not being childless "so that he may be merciful," humbleness, and enough valor to rescue oppressed from their oppressors). 
to state his view of the case in turn, starting with the junior-most so as to avoid intimidation or fear of contradicting more senior colleagues. A judge who spoke in favor of the defendant was barred from recanting, however persuasive later speakers were, but anyone who spoke against the defendant and was later persuaded by the arguments of others would so state. Any judge who spoke against the defendant was required to consider the arguments to the contrary overnight before voting. On the next day, a vote was taken, again in reverse order of seniority; conviction required a vote of at least one judge more than a majority. ${ }^{30}$ As if that were not enough, there was an extra rule that a unanimous vote for conviction resulted in acquittal: seventy-one humans do not agree on anything except when they have not thought hard enough. ${ }^{31}$

There are more requirements that I will spare you. Suffice it to say, first, that the text acknowledges that convictions must have been rare indeed:

A Sanhedrin that kills [i.e., convicts on a capital crime] once a week is called "destructive." R. Eleazar ben Azariah says, "Once in seventy years." R. Tarfon and R. Akiva say, "If we had been on the Sanhedrin, there would never have been a person killed." R. Shimon ben Gamliel says, "They would have increased the number of spillers of blood in Israel." 32

And, second, that by the time the Mishnah, the earliest layer of the Talmud, was finalized, neither the Chamber of Hewn Stone ${ }^{33}$ nor the Sanhedrin existed any

${ }^{30} \mathrm{MISHNAH}$, Sanhedrin 4:2, translated in NEUSNER, supra note 8, at 590 (detailing voting from junior to senior); id. at Sanhedrin 5:5, translated in NEUSNER, supra note 8, at 593 (detailing procedure of waiting day after first argument before convicting and of allowing changes of opinion only to acquit); id. at Sanhedrin 1:6, translated in NEUSNER, supra note 8, at 584-85 (requiring majority of two for conviction).

${ }^{31}$ BABYLONIAN TALMUD, Sanhedrin $17 \mathrm{a}$, translated in 15 STEINSALTZ, supra note 22 , at 179-87 ("R. Kahana said: A Sanhedrin where each one saw fit to convict, acquits him. Why? Because Gemara teaches us the rule to delay [the sentence overnight] to find [arguments for] his innocence, and these are not looking for it.").

${ }^{32}$ MISHNAH, Makkot 1:10, translated in NEUSNER, supra note 8, at 612. The Gemara points out but does not resolve the ambiguity in R. Eleazar b. Azariah's statement. Is it to be taken as a moral claim (a Sanhedrin that executes once in seventy years deserves to be called destructive) or an empirical one (executions were so infrequent that once in seventy years was enough to warrant special distinction as a bloodthirsty court)? BABYLONIAN TALMUD, Makkot 7a, translated in SONCINO, supra note 19. Either interpretation, however, suggests that executions were rare.

${ }^{33}$ BABYLONIAN TALMUD, Avodah Zarah $8 \mathrm{~b}$, translated in SONCINO, supra note 19 (discussing Sanhedrin's exile from Chamber of Hewn Stone forty years before destruction of Temple "because when they saw that murderers were so prevalent that they could not deal with them properly, they said, better we should be exiled from place to place than find them guilty"). 
longer, and ordination was in terminal decline. ${ }^{34}$ It follows that under the Mishnah's rules, Rabbi Akiva had won: there would never be a conviction again.

In short, there is a certain impracticality here. I believe the explanation for this bloodthirsty law that could never lead to a conviction is that the biblical law of crimes was understood to be law that is taught-law to live by-not law that is to be put into practice-law to kill by. Robert Cover taught that law is violence. ${ }^{35}$ This is a violent law that is attempting to adopt Gandhi, to renounce violence altogether. What right have we, mere humans, to impose the law of God on others? If violence is wrong, can judicial violence be right?

A nineteenth century Hassidic rabbi restated the Mishnah's view poetically in a prosaic setting: "To his coachman, [Rebbe Wolfe of Zbaraj] said 'Please throw away your whip. Even if a horse does deserve punishment, what makes you think it is up to you to inflict it?"' 36

Jewish law often seems to have viewed the biblical system as defining an ideal: terrifying punishments that are never carried out. Perhaps the thought was that terror, education, and socialization meant that carrying them out would never be necessary. But this is implausible. Violent punishments cannot deter once it is known that they will never be carried out-I threaten my children daily with hangings by their thumbs, abandonment in front of the television, and various other horrible fates, but they never seem to take it very seriously. Similarly socialization, even in the tight and oppressive communities of a mythical traditional past, will never work all the time with everyone.

Still, one view is unwilling to punish, even when punishment is warranted. In effect it says, only God can judge, so leave the judging to God:

Rav Eleazar son of R. Shimon met an officer who was arresting thieves. He said to him, How can you [detect] them? .. . Maybe you take the righteous and leave behind the evil? He said, and what can I do? It is the king's command.

${ }^{34}$ BABYLONIAN TALMUD, Sanhedrin 13b-14a, translated in 15 STEINSALTZ, supra note 22 , at 133-46, describes the attempt of the Romans to end ordination in the Mishnaic period. Apparently, ordination continued in some form well into the talmudic period. See ROBERT M. COVER, The Folktales of Justice, in NARRATIVE, VIOLENCE, AND THE LAW 188-95 (Martha Minow et al. eds., 1992) (stating that ordination ended in fifth century and describing sixteenth century attempt to revive it); Robert M. Cover, Bringing the Messiah Through the Law: A Case Study, in Nomos XXX: Religion, MORALITY, AND THE LAW 201, 201-04 (J. Roland Pennock \& John W. Chapman eds., 1988).

${ }^{35}$ ROBERTM. COVER, Violence and the Word, in NARRATIVE, VIOLENCE, ANDTHE LAW, supra note 34, at 203, 213; Cover, supra note 6, at 40.

${ }^{36}$ ELIE WIESEL, SOULS ON FIRE 51 (Marion Wiesel trans., 1972). Rebbe Wolfe's use of the tradition illustrates that while the classical arguments are in the context of capital punishment, they need not remain there. Thinkers who question the collective right to execute the guilty, let alone the innocent, must also question the right to beat, fine, or (in our system) imprison them. 
He said to him, Come, I will teach you. Go to a tavern at the fourth hour of the day. If you see a man drinking wine, holding a cup in his hand and napping, ask about him. If he is a scholar and is napping, [it is because] he rose early to study; if he is a laborer, he rose early to do his work; if his work is at night he may have been stretching wires. If not, he is a thief: arrest him.

A report was heard in the House of the King. They said, let the reader of the letter be the messenger.

They brought R. Eleazar son of R. Shimon, and he began arresting thieves.

R. Joshua ben Karhah sent to him: Vinegar son of wine! ${ }^{37}$ How long will you send (moser) the people of our God for execution? [R. Eleazar] sent him the answer: I am destroying thorns from the vineyard. [R. Joshua] sent to him: Let the Owner of the vineyard come and destroy His thorns. ${ }^{38}$

\footnotetext{
${ }^{37}$ The reference is to R. Eleazar's father, R. Shimon bar Yohai, and suggests that the son was not following in the father's ways. See BABYLONIAN TALMUD, Bava Metzia 83b, translated in 5 STEINSALTZ, supra note 22, at 116 (containing R. Steinsaltz's commentary on this passage).

${ }^{38}$ BABYLONIAN TALMUD, Bava Metzia 83b, translated in 5 STEINSALTZ, supra note 22, at 113-19. For further discussion of this passage, see J. David Bleich, Jewish Law and the State's Authority to Punish Crime, 12 CARDOzO L. REV. 829, 836-37 (1991). A similar story appears in the Jerusalem Talmud:

Ulla bar Koshav was wanted by the authorities for a capital offense and fled to Lydda, the town of Rabbi Joshua ben Levi. The authorities came and surrounded the area and threatened to ravage it if Ulla were not handed over. Rabbi Joshua ben Levi then went to Ulla and convinced him to hand himself over.

Up to that time, Elijah the Prophet had made regular visitations to Rabbi Joshua, but then he stopped. Rabbi Joshua fasted repeatedly and Elijah came to him. "Do you think," Elijah asked, "that I would reveal myself to a moser [one who hands Jews over to the authorities]?" Rabbi Joshua replied: "But 1 acted on the basis of a mishnah [a teaching of the Mishnaic authorities, ordinarily binding on later talmudic rabbis]!" Elijah answered: "But is that a mishnah of the pious?" [thus suggesting that some laws should not be obeyed].
}

Jerusalem Talmud, Terumot 8:4, translated in 2 The Jewish Political Tradition (Michael Walzer et al. eds. \& trans., forthcoming 2003) (manuscript at ch. 16, on file with author).

The issue in both stories may be one of cooperation with the (foreign) authorities as much as hostility to criminal law as such. However, some authorities find the key to the Ulla bar Koshav story to be whether Ulla was in fact (or in Jewish law) worthy of the death penalty the authorities planned for him. If he was, perhaps handing him over would be warranted.

For an example of a reading that clearly makes the issue one of justice to Ulla (and to his victim, if any) rather than of the legitimacy of the authorities, see Ephrayim Oshry, 5 She'elot U'Teshuvot, translated in 2 THE JEWISH POLITICAL TRADITION, supra (manuscript at ch. 16, on file with author) (discussing different readings of Ulla story). R. Oshry's responsa concerns whether it is permissible for the Jewish authorities to comply with a Nazi order to select a small group to remain while all others will be deported to their immediate deaths. See id. In that context, the innocence of the "accused" and the illegitimacy of the authorities are unquestionable. The sole issue 
R. Eleazar challenges the frankly amoral, perhaps somewhat consequentialist view of the officer with a retributivist challenge: "Perhaps you take the innocent." He then appears to resolve his own criticism with a magical method of distinguishing the guilty from the innocent. Interestingly, the Talmud, which is entirely capable of criticizing magic or pointing out logical fallacies, does not pause to question the efficacy of R. Eleazar's method. On the contrary, the immediately following stories emphasize that $R$. Eleazar did not make mistakes, even if ordinary mortals following his method might. ${ }^{39}$ The story then, is an implicit criticism of those who, without $R$. Eleazar's magical advantage, dare to arrest when they might be condemning the innocent.

But notice how far-ranging $R$. Joshua's critique becomes if we accept $R$. Eleazar's claim that his methods are fail-proof: R. Eleazar's complaint was "perhaps you take the innocent," but R. Joshua's is, rather, "how dare you arrest the guilty!" It is for God, not men, to eradicate the thorns that God has placed in the vineyard of Israel. Thorns are also part of God's plan or, in nontheological language, even criminals are members of the community. ${ }^{40}$

\section{B. The Failure of Divine Justice: "They would have Increased the Number of Spillers of Blood"}

But how can this be? The Mishnah records an immediate response to Akiva's claim that he would never have voted for a conviction-and to its implicit adoption of his position. R. Shimon ben Gamliel says, "They would have

is whether it is permissible to be complicit in the killing of some people in order to save others-an issue raised by all criminal law where guilt cannot be known with absolute certainty. Although $R$. Oshry ultimately decides that one must do whatever one can to save whomever one can, he by no means views the issue as simple, and most of the authorities he cites suggest that one may not sacrifice an innocent Ulla even to save a whole town. See id.

${ }^{39}$ The passage immediately following the one quoted, supra text accompanying note 37 , describes how R. Eleazar in a fit of pique arrests a laundryman for calling him "vinegar son of wine" to his face; when he calms down and regrets his unjust action, it turns out that the laundryman had committed multiple violations of biblical law punishable by death by stoning followed by hanging. BABYLONIAN TALMUD, Bava Metzia 83b, translated in 5 STEINSALTZ, supra note 22, at 113-19. So, R. Eleazar apparently has Heavenly assistance: even when he violates the most basic principles of due process, justice is done. Id.; see also 5 STEINSALTZ, supra note 22, at 116 (explaining, based on Rashi's commentary, that laundryman and his son had sexual relations with betrothed maiden on Yom Kippur, thus violating at least three different prohibitions). The text then continues with additional miraculous proof of R. Eleazar's merit - his flesh, like the flesh of the perfectly righteous, does not rot even when fat cut out of his body is left out in the sun. BABYlonian TALMUD, Bava Metzia 83b, translated in 5 STEINSALTZ, supra note 22, at 113-19.

${ }^{40} \mathrm{On}$ the significance of membership, see Daniel Greenwood, Beyond the CounterMajoritarian Difficulty: Judicial Decision-Making in a Polynomic World, 53 RUTGERS L. REV. 781, 797-803 (2001) (discussing centrality of membership to understandings of equality). 
increased the number of spillers of blood in Israel. ${ }^{941}$ Thus, if Rabbi Akiva sought to make the criminal law a law to live by, to teach rather than apply, Rabban Gamliel makes the obvious rejoinder: Akiva's ineffective criminal law-to-live-by is rather a law that will lead to more crime and thus more death. Criminals may be members of the community, but their behavior is destructive of it.

God does not make us behave; we must make each other behave. A famous saying makes the point dramatically: "Rabbi Hanina, assistant High Priest, would say, "Pray for the health/peace (shalom) of the government [the word for "government" (malchut) is the one usually used to refer to the illegitimate Roman occupying power] for without it, people would swallow each other alive." "\$2

In the Middle Ages, it was put this way: "If everything is left to stand on the law of Torah, as when the Sanhedrin imposes judgment, the world would be desolate., ${ }^{, 43}$

${ }^{41}$ MISHNAH, Makkot 1:10, translated in NEUSNER, supra note 8, at 612; see supra note 32 and accompanying text. I do not know of any evidence that capital punishment is necessary or even effective, but supervision and punishment of some variety is clearly essential. Rabban Gamliel's basic point seems incontestable: without a criminal justice system willing to convict, crime would increase. Modern research suggests that cooperation itself-the foundation of society-may depend on the willingness to punish. Thus, experimental evidence suggests that people generally are more likely to act according to fairness norms than as "rational" (exploitative) profit maximizers-except when they can exploit others anonymously. See RiCHARD H. THALER, THE WINNER's CURSE 11 (1992); infra note 59. Similarly, people seem generally willing to punish free riders and defectors even when "rational" self-interest would suggest free riding themselves. See, e.g., Ernst Fehr \& Simon Gachter, Altruistic Punishment in Humans, 415 NATURE 137 passim (2002) (providing experimental evidence that humans will "altruistically" punish free riders even at substantial personal cost in order to sustain cooperation).

${ }^{42}$ MISHNAH, Avot 3:2, translated in NEUSNER, supra note 8 , at 678 . The saying appears to echo Jeremiah 29:7, where the reference to a foreign (if not necessarily illegitimate) government is clear.

${ }^{43}$ Bleich, supra note 38 , at 857 ; see also Gerondi (Ran), supra note 4 , at 156-61 (describing divine purpose of Torah criminal law and noting that "punishing criminals in this way alone [i.e., not punishing them] would completely undermine political order: 'murderers would multiply"). Jewish law thinkers suggested that the deficiencies of Torah criminal law could be solved by a parallel system of royal law with harsher punishments and more lenient procedures. See, e.g., id. at 157, 159 (arguing that king, unlike Sanhedrin, may depart from Torah law "to perfect the political order and [to meet] the needs of the hour" and may impose any punishment necessary for political association); BABYLONIAN TALMUD, Sanhedrin 46a, translated in 17 STEINSALTZ, supra note 22, at 191-97 (noting that court may impose punishments not in conformity with T2rah law to make hedge around Torah); 3 THE JEWISH POLITICAL TRADITION (Michael Walzer et al. eds. \& trans., forthcoming 2004) (manuscript at chs. $23 \& 24$, on file with author) (translating additional texts on this topic).

The precise relationship between the two criminal justice systems is difficult and controversial. Suzanne Last Stone, for example, argues that the lenient Siniatic system reflects the "special family relationship that exists between God and Israel and not political communities ruled by an earthly sovereign." Suzanne Last Stone, Justice, Mercy, and Gender in Rabbinic Thought, 8 CARDOZO STUD. L. \& LITERATURE 139, 169 (1996). She contrasts this to the parallel Noahide system binding on all humans which "corresponds with . . . conventional justice . . . dedicated to 
In short, the problem with the law as set out in the Talmud's tractate Sanhedrin is that it would not prevent crime (or more precisely, would not prevent it as effectively as a more punitive law might-even with punitive laws, much of the world has been pretty desolate).

Jewish criminal law, thus, centers around a paradox. On the one hand, as Rabban Gamliel emphasizes, we need fear of punishment to keep people in line. This is a utilitarian, consequentialist defense of criminal law: punishment is justified because otherwise "people would swallow each other alive."

On the other hand, Rabbi Akiva takes a deontic, justice-based, retributive view. Punishment is only justified when it is deserved. Ordinary law is applied by people, not by God. The same God who made us need fear of the law to reduce spilling of blood, also made us incapable of the knowledge that is necessary to justly apply the law. Human beings can never be certain that the law is fully just, that the accused is factually guilty, that the technically guilty deserve punishment, or, as Rabbi Wolfe of Zbaraj points out, even that we are authorized to punish. The only way we can assure that courts will only punish appropriately is by preventing them from doing it at all. ${ }^{45}$ For who are we-who unlike God cannot know the motivations and intentions of our fellow humans-to decide when punishment is deserved, let alone to arrogate to ourselves the right to impose it. Rabbi Akiva's view not only accepts retributive theory but takes it seriously: we must not punish the innocent, but we cannot know who is guilty, and we cannot retribute without the knowledge we cannot have. Justice demands that we not act unjustly; in the criminal justice system, that means we cannot act at all. Rabbi Akiva, then, demands that the judge who dares to punish others act justly himself; as another famous rabbi of the same period said, "Let he who is without blemish cast the first stone. ${ }^{" 46}$ Only God is without blemish. ${ }^{47}$

Rabban Gamliel retorts that justice which encourages murder is no justice at all. The tension has no resolution, but there are attempts.

One attempted resolution is a deep-and ultimately somewhat implausible - faith in an individualized providence. This view, contrary to the spirit of the Book of Job, adds wish fulfillment to its description of the divine system of justice. If human justice fails, God will punish instead:

the preservation of social order through pragmatic and coercive means. It is exemplified by the attribute of strict justice and is well suited to the violent nature of its subjects [i.e., humans]." $l d$. Others have read the texts as originally a debate about a single (ideal) system rather than about two parallel ones.

${ }^{44} \mathrm{MISHNAH,}$ Avot 3:2, translated in NEUSNER, supra note 8, at 678.

${ }^{45}$ See supra note 36 and accompanying text.

${ }^{46} \mathrm{John} 8: 7$.

${ }^{47}$ And there is no guarantee that God will do justice either. See, e.g., Genesis 18:25 ("Will not the Judge of all the world do justice?"). 
R. Shimon Ben Shetah said, "May I never see comfort, if I did not see one who ran after his comrade into a ruin, and I ran after him, and I saw a sword in his hand and the blood was dripping and the killed man was writhing. And I said to him, Evil one, who killed him? It was either you I! But what can I do-your blood is not given into my hands, for the Torah says, 'By the testimony of two witnesses ...' May He Who knows thoughts take vengeance on this person who has killed his comrade." They say that they hadn't moved from there when a snake came and bit him and he died.

But was he deserving of a snake[bite]? R. Yosef said, and the Academy of Hizkiyah taught also, that from the day that the Temple was destroyed, even though the Sanhedrin ceased, the four methods of capital punishment didn't cease. They didn't cease? Surely they did cease.

Rather, punishment by the four methods of execution did not cease. One who is liable to stoning either falls from the roof, or is trampled by a wild animal. One who is liable to burning, either falls into a fire or a snake bites him. One who is liable to decapitation, either is handed over to the malchut [foreign government] or bandits come on him. One who is liable to strangulation, either drowns in the river or dies of diphtheria [thought of as a disease of strangulation]. ${ }^{48}$

But sometimes we must wait a long time indeed for Heaven's justice. For those of little faith or patience, snakebites are, I fear, likely to be only slim consolation for the failure of the Sanhedrin system of Torah law ever to achieve a conviction. The system of snakebites and accidents requires a confidence in God's simplicity that any observer of the ways of the world (let alone reader of Torah) should question.

${ }^{48}$ Babylonian TALMUd, Sanhedrin $37 \mathrm{~b}$, translated in 17 STEINSALTZ, supra note 22 , at 69-75 (emphasis added). Abravanel offers a similar view:

Nor is a king required in Israel to punish [criminals] . . in accordance with the needs of the hour, because God gave that authority to the Great Court, the Sanhedrin, as I explained [in my commentary above]. Furthermore, God has informed us that if a judge who acts in accordance with just law should acquit a wrongdoer, God Himself will punish the wicked person with His great judgment, as it is written, "Keep far from a false charge; do not charge death on those who are innocent and in the right, for I will not acquit the wrongdoer" (Exodus 23:7). This means, "I will punish him for anything for which you are unable to punish him legally." Thus, it has been explained that these three things-that is, delivering them through war, laying down laws and commandments, and determining occasional punishment outside the law-are all performed by God for His people. Therefore, God is their king, and they have no need for a [human] king for anything.

ISAAC ABRAVANEL, COMMENTARY TO DeUteronomy, translated in 1 THE Jewish POLITICAL TRADITION, supra note 4, at 153 (citations omitted). 
One assumes R. Joshua's retort-"let the Owner of the vineyard weed His thorns"- would not satisfy those who, with Rabban Shimon ben Gamliel, Rabbi Hanina, and Thomas Hobbes, believe that without laws and civil authorities "people would swallow each other alive." ${ }^{49}$ On this justification from necessity, Jewish law proceeded to create a second criminal justice system not based on Torah law at all but rather on the need to keep society functioning. ${ }^{50}$

God's ideal law failed to preserve human society. So the legal system created a parallel, human, criminal justice system based on human law without divine sanction. Still, R. Joshua's concerns--that even when we know (in a sense not usually possible to humans) that someone is guilty, only God may justly punish-give a framework even for those of little faith who are not willing to leave God's work to God alone.

\section{Creating Human Criminal LaW: The Justification FROM NECESSITY AND THE EFFECTIVENESS CRITERION}

This reading of Rabbis Joshua and Akiva, thus, makes the dramatic claim that in a system of absolute justice, criminal law can be enforced only by God. Generalized, this same argument applies to religiously based law as a whole, including the version of restorative justice championed by Charles Colson. If the law is divine and its intention is to create a holy people, only the Owner of the vineyard has either the right or the ability weed His thorns.

At the same time, Jewish law acknowledges and accepts Rabban Gamliel's objection that these demands of justice hardly seem practical. We cannot leave punishment to God, because without human justice, humans will commit more crimes. Morever, this concept of justice does not even seem just, to the extent that the absence of a functioning system of criminal law invites more injustice. Presumably, that is why creating a judicial system is one of the seven Noahide laws that Jewish law insists are binding on all humans everywhere. ${ }^{51}$ What then can we say about human, imperfect, not divine criminal law, criminal law that is motivated by the necessity of preventing people from "swallowing each other alive"?

First, criminal law is justifiable, if it is justifiable at all, only by reference to the needs of society. It is not to redress the balance of the Universe, cleansing the

${ }^{49}$ Supra note 44; see also ThOMAS HobBes, LeVIATHAN 186 (C.B. MacPherson ed., Pelican Books 1968) (1651) ("'[M]en have no pleasure, (but on the contrary a good deal of griefe) in keeping company, where there is no power able to over-awe them .... And the life of man, solitary, poore, nasty, brutish, and short.").

${ }^{50}$ See, e.g., supra note 43 (citing descriptions of parallel king's justice system).

${ }^{51}$ See MAIMONIDES, MISHNEH TORAH, Kings 9:1, translated in YALE JUDAICA SERIES, supra note 8, at 230-31; Suzanne Last Stone, Sinaitic and Noahide Law: Legal Pluralism in Jewish Law, 12 CARdozo L. Rev. 1157, 1163-71 (1991). 
land of blood guilt as Torah law demands. Nor is it for the personal salvation or redemption of the criminal. Those are issues of absolute justice that must be left to He-who-knows-thoughts. ${ }^{52}$ Nor, except in the crudest form, can it be for the assuagement of the pain of the victim. Those goals must be left to time and individual relationships, where hurt feelings can be mended and pain assuaged in ways that are not the province of the courts. For the courts to get involved in the revenge business requires the kind of knowledge and authority that $\mathrm{R}$. Joshua teaches we cannot have.

Coercing apologies or forgiveness, it seems to me, is no less fraught with epistemological difficulty. Criminal and victim may be able to reach a resolution; however, the process seems ill suited to routinization and institutionalization. If judges lack the knowledge necessary to judge, surely they are unequipped to take on the more difficult task of restructuring human relationships.

Rather, punishment is justified only if it reduces the likelihood of crime in the future. ${ }^{53}$ The purpose of human criminal justice is to prevent people from swallowing each other alive, not to weed the vineyard or purge the land of blood guilt.

Restorative justice rhetoric sometimes makes a distinction between offenses against the majesty of the king and offenses against society: criminal law, we heard in this Symposium, is prosecuted by the state and imposes punishments on behalf of the state because it redresses offenses against the king's peace; restorative justice aims instead to restore society. ${ }^{54}$ Jewish law, like modern democratic law (one hopes) rejects the alleged goal of protecting the king's

${ }^{52}$ See supra note 47.

${ }^{53}$ The formal structure of Jewish law makes clear, as our First Amendment ought to in the American context, that the secular law must rely entirely on secular justifications. Torah law can be justified as the word of God, but it must follow the word of God all the way-and, as we have seen, that means that convictions are impossible. The law of necessity, or the law of the king (as it is generally referred to in Jewish law sources), must be defended in purely human terms-not because it echoes in some way the Torah law, but because it works to maintain society. For further discussion of the law of the king, see 3 THE JEwISH POLITICAL Tradition, supra note 43 (manuscript at ch. 23, on file with author); Bleich, supra note 38, at 830-33.

${ }^{54}$ See, e.g., Erik Luna, Punishment Theory, Holism, and the Procedural Conception of Restorative Justice, 2003 UTAH L. REV. 205, 227-29. I am not a criminal law scholar, so perhaps my evidence is suspect, but this supposedly conventional wisdom is news to me. Criminal prosecutions are brought by the state in the United States (although in some other Western legal systems, citizen complainants have the right to force the prosecutor to commence an action or to commence one on their own). But that alone is not enough to infer that the United States or Western legal cultures generally view crimes as "public wrongs" in which the state is the victim or that "[t]raditional approaches ... overlook ... social relationships." Id. at 229. On the contrary, standard liberal notions of the separation of state and society strongly suggest that the state is merely vindicating an injury to society.

Overblown rhetoric aside, the restorative justice point is sound: American political discourse, at least, has often underplayed the importance of social relations in creating effective criminal law. 
majesty. The state has value only to the extent it serves its citizens; one protects the state only in order to protect society. Conversely, when the state intervenes to punish crime it does so as an agent for society's peace, not the king's majesty-all criminal justice, not just the restorative justice variety, must be motivated by the need to preserve society. On the Jewish law side, one does not pray for the health of the malchut (the foreign government) ${ }^{55}$ because of the majesty of the king, but because it alone can keep the peace that society needs. Similarly, modern democratic states do not claim the divine right of kings or to be fascist embodiments of the national spirit. The state has no claim to value in and of itself; it is only a tool for its citizens. Accordingly, the state punishes (or should punish) not to vindicate its own dignity - an absurd concept in any liberal politics—but rather to protect society.

On this view, restorative justice differs in its means but not in its goals from conventional criminal law in a democratic state. The defense of restorative justice must be the same as the defense of any punitive system: restorative justice is valuable if we have reason to believe that it will lower the crime rate at a morally acceptable cost or lessen the costs of unpreventable crime without inducing more. Grander claims-doing justice, restoring moral balance, earning salvation - demand a type of justice (the absolute justice of the Torah system or its equivalent in other systems and other languages) that we cannot make operational any more than could Rabbi Akiva.

Criminal law, then, requires a utilitarian defense of the type Rabban Gamliel is looking for: it must work to reduce crime. We might refer to this as the effectiveness criterion.

\section{A. Distinguishing Punishment From Oppression}

The effectiveness criterion generally rules out the most shocking claim of utilitarian punishment theory: that it sometimes may be justifiable to "punish" the innocent in order to generally deter others from crime. It seems to me rather that it mandates something quite close to a requirement of due process and proportionality of the offense to the penalty.

Violence that is not deserved is not punishment, but crime or oppression or terror or war. As Holmes put it, "even a dog distinguishes between being

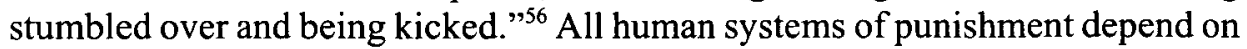
the criminal and the intended-to-be-deterred understanding the difference between punishment and simple violence. Negative reinforcement alone is never enough.

\footnotetext{
${ }^{55}$ See supra text accompanying note 42 .

${ }^{56}$ Oliver Wendell Holmes, JR., The COMMON LAW 3 (1881).
} 
Punishment may induce repentance and reform. ${ }^{57}$ But crime, oppression, and terror more typically induce resistance, and the difference between punishment and oppression is only legitimacy in the eyes of the punished and their community. Were that not so, Ariel Sharon's violence would long since have deterred the Palestinians, or vice versa; Al Qaeda's attacks would be bringing us around to their view of the world. Indeed, the difference between crime and punishment itself is based in legitimacy; were that not so, ordinary judges would be liable for assault or worse each time they decided a case.

When state violence is understood as illegitimate, prison becomes a rite of passage, a mark of true patriotism, a school of resistence or leadership, or just a fact of life, as in pre-Revolutionary Russia, the Soviet Gulags, and the prisons of colonial governments everywhere. Martin Luther King, Natan Scharansky, Nelson Mandela, and a host of other national liberation heroes all served time in prison, but instead of deterring their followers it goaded them on. They and their movements classified the state violence not as punishment but as oppression.

Similarly, violence that is random is neither punishment nor oppression: it is just a fact of life, like an earthquake or other disaster. Earthquakes do not teach that one ought to obey social norms any more than does oppression. ${ }^{58}$ State systems are no different. A criminal "justice" system that randomly imposes violence on the not-guilty is not only unjust but is also unlikely to actually work at reducing crime. Stalinism's legacy includes a society of mass lawlessness.

To be coherent, the very concept of punishment must contain within it a theory of justice, and to be effective, that theory of justice must be accepted by the target population and not merely the enforcers. Naked negative reinforcement is not punishment and will not function as such until the target population accepts it as just or deserved.

Violence is only likely to be effective punishment if it is viewed as legitimate. Specific deterrence works only if those upon whom it is imposed accept it as legitimate, as punishment to be accepted rather than oppression to be resisted or violence to be avoided. General deterrence requires the same of those who fear its imposition. Thus the vulgar utilitarian claim that since punishment is meant to deter, there is no reason that only the guilty be "punished" can stand only if, implausibly, the targets of utilitarian terror are unable to tell the difference between a fair system and the opposite. But people are notoriously good at

${ }^{57}$ More specifically, the social stigma associated with punishment may deter. See, e.g., Daniel S. Nagin, Criminal Deterrence Research at the Outset of the Twenty-First Century, 23 CRIME \& JUST. 1, 4 (1998) (reviewing research indicating that punishment deters only to the extent that it creates social stigma). In my terminology, socially-imposed violence without social stigma is not perceived as punishment but as something else-oppression or simply a fact of life.

${ }^{58}$ Unless, of course, natural catastrophes are reinterpreted as punishments, caused by God's judgments about human actions. Compare Jeremiah 4:24 (predicting earthquakes as punishment), with Isaiah 29:6 (interpreting earthquake as reward). 
detecting unfairness, particularly when they are its victims. Violence that the imposers know is not legitimate is highly unlikely to be perceived as legitimate. It is far more likely that enforcers will fool themselves into thinking that their system is just (and perceived as just) than that they will fool the target population, particularly if enforcers have a failure of identification with the target, for instance because they see the target group as different from themselves (an underclass, national or racial minority, innate criminal types, and so on). Good faith is not enough, but it is an absolute minimum for legitimacy. ${ }^{59}$

Some would argue that the success of totalitarian and absolutist states in reducing crime disproves my claim here. Similarly, one could argue that the success of criminal elements in maintaining their variety of social order in certain neighborhoods at certain times demonstrates that terror alone-without legitimacy - can work. The analogy demonstrates the problem: without legitimacy, there is no difference between crime and justice. Even to claim that terror can reduce crime, we must have some basis for distinguishing terror from crime.

Even if there were an important difference between illegitimate state violence and illegitimate private violence (and it is not immediately obvious that there is), the violence necessary to eliminate (private) crime without the help of legitimacy is simply so great that it isn't worth it. If the price of ending crime is living in Castro's Cuba, Stalin's USSR, or Saddam's Iraq, the solution is no improvement over the problem.

But the premise is also highly questionable: at least after the fact, the supposed law abidingness of subjects of the Soviet Union seems to have been an illusion. This seems to me utterly predictable. Absolute states are by definition lawless states; they cannot teach or breed respect for the law but only fear of power. Even if we do not count the crime of the state itself (and I see no reason why we should not), absolute states seem more likely to hide crime than eliminate it. Fear breeds evasion and resistence, covert if not overt. Perhaps the Soviet citizens were not openly criminal or in open rebellion until the very end, but they did become experts at quiet cheating early on.

\footnotetext{
${ }^{59}$ Tom Tyler's work demonstrates the importance of perceived legitimacy in making punishment effective. See Tom R. Tyler, Procedural Fairness and Compliance With the Law, 133 SWISS J.ECON.\& STAT. 219, 219-40 (1997). Ultimatum games suggest the same. See, e.g., THALER, supra note 41 , at 11 (reporting research indicating that students, other than economics students, free ride at relatively low rates, especially when free riding is observable); Christine Jolls, $A$ Behavioral Approach to Law \& Economics, 50 STAN. L. REV. 1471, 1490 (1998) (describing Ultimatum game and research indicating that people make offers they perceive as fair even in absence of sanctions); Joseph Henrich et al., "Economic Man" in Cross-cultural Perspective: Behavioral Experiments in 15 Small-scale Societies 13-20 (Santa Fe Inst., Working Paper No. 01-11-063, 2001), available at $\mathrm{http} / / \mathrm{www}$. santafe.edu/sfi/publications/wpabstract/200111063 (describing results of playing Ultimatum and related games in various societies, generally supporting notion that behavior is far more strongly influenced by normative views than by incentives or self-interest).
} 
The argument here is of a rule utilitarian type. It is more likely that we will reach an effective criminal law by avoiding the ultimate issue (effectiveness) and instead thinking about a fair criminal law. In the name of effectiveness or necessity, it is too easy to commit injustices that undermine the very effectiveness we aim for. Just as rule utilitarians are skeptical about the ability of individuals to make utilitarian calculations under pressure of events and therefore recommend instead rules that look remarkably like ordinary morality, so too effective criminal law requires that we put aside images of lone cowboys shooting the villains into submission or charismatic preachers converting the sinners, and instead think about justice. As Maimonides counsels in his discussion of courts that impose punishments on those who are not liable to punishment under Torah law: "Let not human dignity be light in the court's eyes .... The court must be careful not to destroy their honor but rather only to enhance the honor of God ... [by] acting according to the Torah's laws and regulations." 60

Maimonides' argument is similar to a common justification of modern restorative justice practice, and indeed to broader sociological theories of perceived legitimacy such as those associated with Tom Tyler ${ }^{61}$ To teach norms, we must follow them. Ultimately, effectiveness - the success of the criminal justice system in reducing crime - depends more on whether we can successfully inculcate values of respect than on deterrence, incapacitation, fear, or revenge.

Or, to put the same thing another way, deterrence only deters to the extent that those we hope to deter accept the system as fair-otherwise, rebellion or resistence are likely to seem more appropriate responses. When the courts follow norms that are accepted by society at large (and the subsections to which potential criminals belong), then legal sanctions will be accepted as legitimate punishment for bad acts, and legal norms will be enforced by social sanctions that are far more influential than anything the law alone can provide. When they are not, the law's reach is likely to be limited, and its violence excessive. Effectiveness requires legitimacy and legitimacy requires acting legitimately. Only if the courts respect human dignity can the criminal law teach respect for human dignity.

There are, of course, controversial issues of what legitimacy or fairness require. But the basic requirements of due process-permitting defendants an opportunity to defend themselves with a fair procedure before an unbiased tribunal, requiring a strong showing of factual guilt before imposing punishment - are clear and widely agreed upon. So too are the basic ideals of

\footnotetext{
${ }^{60}$ MaImONIDES, Mishneh TORAH, Sanhedrin 24:10, translated in YALE JUDAICA SERIES, supra note 8, at 75 (stating that court may take actions it deems necessary for "needs of the hour" if it does so "for the sake of Heaven," and "without the honor of creation being light in its eyes"); cf. id. at Sanhedrin 24:4, translated in YALE JUDAICA SERIES, supra note 8, at 73 (stating that court is permitted to punish without following Torah law if needed as temporary measure to fence and strengthen law).

${ }^{61}$ See supra note 59.
} 
restitution and restorative justice: if you hurt someone you should apologize, and if you broke something, you should replace it. To the extent that restorative justice focuses the criminal justice system on issues of justice and on making that justice apparent to criminals, victims, and society at large, surely the criminal law will be more effective in reducing crime.

This section began by questioning the restorative justice goal of repairing human relationships. That task is too great for merely human judges. ${ }^{62}$ But that critique may not apply to a more modest version, in which the human goal of reducing crime and its damages is pursued in part by seeking to help the criminal justice system (through family conferencing and related restorative justice techniques) facilitate-rather than coerce-healing, or provide a framework in which individuals, if they are so inclined, will be supported in rebuilding or restoring relationships.

The restorative justice foci on mutual dignity, on censuring crime rather than criminals, on inclusiveness and empowerment, all seem fully in keeping with the older insights of the Jewish law tradition: even a sinner is a member of the community. ${ }^{63}$ And criminals (or potential criminals) who are treated as members of the community are more likely to accept that they are members of the community and therefore more likely to act like members of the community. This congruence is no substitute for real data, but in the absence of convincing empirical results, it may provide some reason to be less skeptical of radical changes in the way we do criminal law than one might be otherwise.

\section{HUMAN LAW AND RESTORATIVE JUSTICE: THE POWER AND POVERTY OF MEDIATION}

The first message of the Jewish law texts, the primacy of the effectiveness goal, is somewhat at odds with at least the more millenarian versions of faithbased restorative justice: it counsels restricting the state to smaller goals, to seeking peace rather than redemption. The second message is that the community must remain central at all times: it is only the needs of the community that allow judges to play God. This latter theme fits better with the restorative justice project.

The centrality of community suggests that if reconciliation is possible, it must be done first. It is not possible for a criminal to "pay his debt to society" by serving time in prison, any more than it is possible to attain atonement for sins against people by praying at Yom Kippur. Prayer can win forgiveness for sins against God, but sins against people require making peace with the people against whom you sinned. Similarly, even if prison could atone for the abstract crime

${ }^{62}$ See supra text accompanying notes $51-53$.

${ }^{63}$ See, e.g., BABYLONIAN TALMUD, Sanhedrin $44 \mathrm{a}$, translated in 17 STEINSALTZ, supra note 22 , at $165-71$ ("[E]ven when Israel sins, they are Israel."). 
against the social order (but atonement is one of those things best left to a divine criminal law system in which convictions and punishments come only from Heaven), the hurt to real, individual people must be healed by more personal processes. This, I take it, is a central claim of the restorative justice movement, and it seems reasonable to me.

For a criminal to reform, he must follow the same path as Maimonides sets out for a sinner: first, to make whole the damage he did; second, to ask for forgiveness from both the individual victim and the community; third, to resolve not to do it again and state his resolution to the community in public; and last, to change his life-his friends, his tastes, his usual way of going about life, even his name-so that in fact he does not do it again. ${ }^{64}$

A criminal who reforms in this way is, perhaps, a criminal who need not be sequestered, need not be imprisoned or executed. Unfortunately, we have no better way of knowing who has undergone such a genuine reform than we have of knowing who was genuinely guilty in the first place; certainly, the fact that a criminal has accepted this religion or another one is thin evidence on which to change a sanction. To the extent that faith-based restorative justice seeks to cure the criminal, I worry that God-players will overplay their hands. Sudden conversions made under the threat of the regular criminal sanctions smell too much of the bad old days of holy war.

But to the extent that restorative justice processes encourage some criminals to reintegrate into society, to apologize to their victims and make them whole to the extent possible, they are moving in the direction of healing society, not merely souls. The message of the effectiveness criterion is, it seems to me, that the test must be empirical: does the community-based discussion, mediation, and plan in fact make victims feel better, reduce recidivism, or reduce crime?

\section{A. Jewish Law and the Problems of Mediation}

As we have seen, the Torah criminal law as explained in the Talmud cannot function as a coercive system of social control. Instead, Torah criminal law, to the best of my limited knowledge, has functioned as an instrument of social control primarily as a teaching tool. It is law to be taught and debated, not law to be implemented; law as a symbol rather than law to direct state violence. If kids spend enough time arguing about right and wrong, they will understand that they should not commit wrongs. In any event, during the most dangerous years, the young men will be locked up in school debating instead of fighting, without time for crime. There is much wisdom in this approach: if we had more young men in school - or at useful and productive jobs, in the Peace Corps or similar volunteer

\footnotetext{
${ }^{64}$ MAIMONIDES, MishNeH TORAH, Teshuva $\mathrm{ch} .2$.
} 
enterprises, in organized sports activities, or the like-we would surely have fewer in prison.

In the eras when Jewish law also functioned as an instrument of social violence and coercion, it did so as a matter of human law, not divinely commanded Torah. The tradition that the king or the foreign government is permitted (or required) to institute an effective criminal justice system was extended to self-governing Jewish communities, to justify Jewish towns in promulgating and enforcing codes of criminal law with no resemblance to the Torah code. In order to "restrain the current generation" or to "meet the needs of the hour" the authorities were permitted to take any measures necessary to effectively reduce crime. ${ }^{65}$ By the Middle Ages, it seems to have been generally accepted that communal officials could impose fines and corporal punishment or even-at least in some places and some times-turn accused criminals over to the gentile authorities, without regard to the elaborate rules of Tractate Sanhedrin.

To my limited knowledge, Jewish communal law often emphasized restitution, fines, and shame. Criminals should feel the social hurt they have caused, and should heal it where they can. The first step, where possible, is restitution: Jewish law does not make our careful distinction between tort and criminal law, so even in criminal cases, the criminal must make the victim whole. And, since Jewish law, again unlike American law, makes little distinction between religious and social obligations, the rabbinic courts will encourage the criminal to genuinely repent - the Jewish word is "return," return to the law and especially to the community. Beyond that, following the model of the Torah, a fine is due, generally paid to the victim rather than the community. The ban-separation from the society itself-was often the ultimate punishment for the worst of crimes. Imprisonment, which is not mentioned in the Torah system, does not often appear in the texts with which I am familiar, perhaps due to the overwhelming value of maintaining the community. Indeed, ransoming prisoners held by the gentiles was considered one of the most important communal responsibilities, sometimes taking priority over even basic communal functions such as feeding the poor or financing the religious and educational institutions. ${ }^{66}$ On the other hand, turning offenders over to the gentiles (notwithstanding R. Joshua's disapproval) clearly happened, so any standard criminal justice techniques employed by host societies became part of the Jewish law system by

\footnotetext{
${ }^{65}$ See, e.g., RABBi SOLOMON B. ABRAHAM ADRET (Rashba), RESPONSA 3:393, translated in 1 THE JEWISH POLITICAL TRADITION, supra note 4, at 402-03 (justifying communal regulation by doctrines of "needs of the hour" and "restraining the current generation").

${ }^{66}$ See, e.g., MAIMONIDES, MISHNEH TORAH, Gifts to the Poor 8:10-13, translated in THE CODE OF MAIMONIDES(MISHNEH TORAH), BOOK 7: THE BOOK OF AGRICULTURE 82-83 (Isaac Klein trans., Yale Judaica Series No. 21, 1979) (ruling that ransoming captives takes precedence over feeding poor or building synagogue, even if captive is being held for failure to pay debt).
} 
incorporation, so to speak. ${ }^{67}$ The law in practice, however, seems often to have varied from the law in the books. In practice, adjudicators, conscious of the high cost of presuming to take on the God-like role of judge, often seek to act as mediators instead. ${ }^{68}$ They seek to bring the parties to an amicable agreement, not to impose the will of the community on the criminal.

Mediation and reconciliation are among the key goals of the restorative justice movement. But mediation comes with an obvious drawback: mediation necessarily reaches a conclusion that reflects the initial power relations between the parties. Genuine mediation cannot redistribute power, unless the powerful voluntarily agree to give up their advantages. ${ }^{69}$ This weakness of mediation is a serious problem in criminal law, which is always about redistributing power. On the one hand, criminal law must restrain the socially powerful from abusing their power-King David from killing Uriah in order to conceal his adultery, King Ahab from killing Naboth to seize his vineyard, modern corporate chief executives from evading sales taxes or pollution controls or distorting economic reporting for private profit, the rich from bribing public decision-makers, and so on. ${ }^{70}$ Mediation can offer no counterweight to the powerful. On the other hand, even the crimes of the underclass are abuses of power, most obviously in the crude physical power of violent street crime. An ancient aphorism says that the presence of elderly moneychangers on the street corners (easy targets for muggings) is the surest sign of a just (and sufficiently powerful) government. Mediation is unlikely to redress these imbalances of power either.

Jewish law accounts are plagued by the problem of the powerful person who ignores the mandate of the court-the person who uses connections in the gentile world to overturn the court's mandate, or the person who simply refuses to agree

\footnotetext{
${ }^{67}$ The medieval texts rarely discuss capital punishment in practical terms. However, it is difficult to infer a principled objection from this since in most countries at most times, Jewish communal privileges of self-government did not extend to imposing capital punishment.

${ }^{68}$ BABYLONIAN TALMUD, Sanhedrin $6 \mathrm{~b}$, translated in 15 STEINSALTZ, supra note 22, at 52-59 ("Rabbi Joshua ben Karhah said, 'it is a commandment to compromise."); MAIMONIDES, MISHNEH TORAH, Sanhedrin 22:4, translated in YALE JUDAICA SERIES, supra note 8, at 66-67 ("The more a court uses arbitration or compromise, the more it is praiseworthy.").

${ }^{69}$ See Greenwood, supra note 40 , at 827.

${ }^{70}$ II Samuel 11:1-12:23 (describing and condemning David's murder of Uriah); I Kings 15:5 (condemning David for matter of Uriah); id. 21:1-29 (condemning Ahab for his behavior towards Naboth). Jewish law had great difficulty with the problem of restraining the king. See, e.g., MishNAH, Sanhedrin 2:3, translated in 1 THE JEWISH POLITICAL TRADITION, supra note 4, at 139 (stating that "the King neither judges nor is judged"). Note that the BABYLONIAN TALMUD, Sanhedrin 19a, limits this Mishnaic rule to unjust kings only, describing an incident where the Sanhedrin's fear of Hasmonean King Yannai (ruled 103-76 B.C.E.) led to God striking judges dead. Id. Michael Walzer describes this failure to construct a mechanism for supervising and limiting kings as the "central problem of Jewish political thinking." 1 THE JewiSh POLITICAL TRADITION, supra note 4 , at 141 .
} 
voluntarily to the restitution the court sees as necessary. ${ }^{71}$ At this point the historical system seems to have simply given up: there was nothing to do about the person who ignores social sanctions, but wait for God to send a snake. And sometimes one must wait a long time indeed for God or snakes.

The Jewish law experience suggests then that a central theoretical and practical issue for the restorative justice movement should be ensuring that mediation does not become a vehicle for ratifying existing injustices. It is encouraging to note that practitioners and theorists of the movement seem well aware of the issue. ${ }^{72}$

In Jewish law, mediation often resulted from a fear of doing injustice even in the name of justice. "Let the Owner of the vineyard remove His thorns" remained a powerful refrain even in the human system designed only to reduce crime. The motive of mediation in restorative justice is rather different: an empirically based belief that treating criminals as members of the community, confronting them with the results of their deeds, and incorporating their victims into a resolution will both reintegrate criminals and appease victims, lowering both the crime rate and the pain crime causes.

Critically, restorative justice processes, unlike traditional Jewish law, operate in the strong shadow of conventional criminal law of powerful states. So long as either side may invoke the state procedure in place of the restorative justice one, mediation is unlikely to deviate far from the solutions the state would otherwise impose (more precisely, any such deviations are likely to be Pareto optimal improvements over the state solution, since movement away from the state solution requires consent of all sides).

The shadow of conventional criminal law obviously lessens the problem of mediation ratifying existing power relationships, but conversely creates a real potential that mediation will become, or be perceived as, a mere ritualistic ratification of imposed solutions. Ritualized condemnation, apology, forgiveness, and catharsis always threatens to become an empty masquerade where participants follow the script without the emotional contact necessary to achieve restorative justice's ambitious goals. ${ }^{73}$

The two goals are in necessary conflict. If mediation is to result in real catharsis and genuine reconciliation, it must reflect the actual feelings and real

${ }^{71}$ See, e.g., JACOB WEILL, SHU" T MAHARI WEILL \#157, translated in 3 THE JEWISH POLITICAL TRADITION, supra note 43 (manuscript at ch. 23, on file with author) (stating, in fifteenth century ruling of German rabbi, that in light of number of violent people who do not respect law, it is not necessary to risk bodily injury to enforce court rulings).

${ }^{72}$ Braithwaite, supra note 1 , at 5 (describing beginnings of restorative justice movement in concern that crimes of powerful went unpunished).

${ }^{73}$ Indeed, Braithwaite reports at least one instance where a restorative justice scheme degenerated into "sham reparation," even including dictated letters of apology. Id. at 21-22 (providing inconclusive evidence about restorative justice programs' ability, in real life, to navigate conflict between need for real mediation and need to reach predetermined just result). 
values of the participants. On the other hand, if it is to help in imposing society's values, it must reach a more or less predetermined range of results. Success thus requires, first, that the criminal accept in some sense the social values that condemn his act, and second, that the mediators be skilled enough to allow the participants to come to this conclusion on their own. This is a practice that will require skilled and sensitive practitioners; a rule of humans and not merely laws. ${ }^{74}$

\section{B. Restitution, Reintegration, and Return}

Both the restorative justice idea and Jewish law emphasize restitution. Our American law probably underutilizes restitution-when criminals can make the victim whole, it seems elementary that they should, and artificial to separate the restitution claim into a separate tort action. In particular, tort law, with its emphasis on monetary damages collected by judicial process, may be largely useless in the petty crime arena. A restorative justice conference and agreement could generate effective restitution that would be economically impossible to achieve in a tort action.

Restorative justice advocates also make the somewhat surprising claim that they are able to win genuine apologies from defendants. ${ }^{75}$ Apologies matter, as any parent (or student of international conflicts) knows. If restorative justice processes win them, they are achieving a powerful form of nonmonetary restitution that rarely happens in court and would never be part of a court order in a litigated criminal or tort case. To be sure, good lawyers for guilty defendants in both civil and criminal cases know that a timely apology will make settlement discussions far easier, but the actual process of preparing to defend in court and defending itself often seems to leave litigants and lawyers in a defensive psychology poorly situated for apology and compromise.

Just as important, restorative justice shares with traditional law an emphasis on affirming the criminal's membership in the community. American imprisonment "upstate" deliberately separates our criminals from society. Presumably, this separation helps create a criminal subculture that can evolve differently and apart from the mainstream one. Successful criminal law, more likely, would bring criminals back into the dominant culture. Reintegration, rather than sequestration, ought to be the goal.

Criminal law is a teaching tool-including for those not directly subject to it—and we seem, in some parts of our country, to have lost control of the lesson

\footnotetext{
${ }^{74}$ See generally HANINA BEN-MENAHEM, JUdICIAL DEVIATION IN TALMUdic LAW: GOVERNED BY MEN, NOT BY RULES (Neil S. Hecht ed., 1991) (arguing that Babylonian Talmud, unlike Jerusalem Talmud, subordinates rules to sound judgment of adjudicators).

${ }^{75}$ Braithwaite reports that victims in Canberra received apologies in most cases and apparently accepted them as genuine, since victims reported in similarly large numbers that they left the conferences less angry. Braithwaite, supra note 1, at 24.
} 
we are teaching. It ought to be one of inclusion, mutual respect, demand for civil behavior, and an emphasis on the mutual dependence that people have who live together in a common society. I do not see how that lesson can be taught by excessive violence: one does not educate children to be good parents by beating them, and it seems unlikely that you can socialize the underclass into middle class norms by massive prison sentences for trivial drug offenses, racially skewed decisions about when to apply the death sentence, or, most significantly of all, without genuine middle class employment possibilities. When violations occur, we should be using the powerful sanctions of social pressure more than we do: publicly humiliating those who are still involved enough in society to be humiliated and shamed; offering opportunities to make reparations and even to repent for those who wish to be reaccepted.

Still, though, Jewish history, indeed human history, makes clear the limits of this limited criminal law. There are times when we must stand up in outrage at offenses against our common morality or the norms of society. There are crimes for which no restitution and perhaps no human forgiveness is possible. Then violence in return for violence indeed may be the only answer-but only if it works. The justification for criminal law must be that in fact it reduces crime.

\section{CONCLUSION: THE RISKS OF RELIGIOUS LANGUAGE IN A PLURALIST SOCIETY}

The effectiveness criterion suggests that restorative justice must be judged, first and foremost, on whether it works. Does it cause criminals who would otherwise reject the legitimacy of their punishment to accept it as educational? Does it lower recidivism rates? Does it make victims feel better? Those are at least in part empirical questions where law professors ought to fear to tread.

I will make one final point, however, about the issues raised by this particular panel, on the use of particular religious traditions in the secular law of a liberal limited state governing a mixed multitude of a people. It is hard for me to imagine the circumstances under which American criminals would accept as legitimate punishment meted out and justified in the language of and according to the standards of religious traditions other than their own.

The language of Christian repentance is as foreign to me as, I imagine, the story of weeding the vineyard is to most of you. Generic or specific Protestant rhetoric undoubtably will speak to many others as it spoke to Charles Colson. Nonetheless, we are a many-textured mixed multitude, exiles from many Egypts, not the inheritors of a monolithic autochthonous tradition sprung from the land 
itself. $^{76}$ Many of us are de-churched, in many cases for several generations already. Those who are not, hear different resonances from different words: the Old Testament of vengeance is not the Torah that I read. ${ }^{77}$

Faith-based initiatives draw their power from a specific faith. But in a pluralistic society that same power will be their downfall. If restorative justice were to mean, as Colson would have it, accepting Jesus, repentance, and mutual forgiveness, it would be too close to tent revivalism to speak to many of us. If the words explaining the violence of criminal law are foreign, the violence of the law risks being perceived as merely arbitrary. And the effectiveness criterion guarantees that if criminal law is perceived as illegitimate, it will be. Criminal law must be accepted to work and it must work to be acceptable. Therefore, it must aim for the common denominator in its language and teaching. In short, we must, however regretfully, avoid the intoxicating particularism of revivalist and messianic religion.

Beyond this largely linguistic point, there is a larger problem with the religious aspiration.

The liberal tradition has long taught that redemption and atonement, indeed love, are rather higher goals than the state should aspire to ${ }^{78}$ When restorative justice advocates contend that they aspire to "justice [that is] administered with love," 79 I fear that the relevant text is less likely to be the Sermon on the Mount than One Flew Over the Cuckoo's Nest or Animal Farm. States that aspire to perfection typically create something rather less than that: the Ayatollah's Iran, the communists' USSR, the Puritans' New England, or Cromwell's civil war. The state should aim lower, not for perfection but just for peace ${ }^{80} \mathrm{It}$ is the needs of civil peace that justify its use of force, not the desire to bring criminals to a state of grace. In the name of love and redemption, many crimes can be committed that humble mutual respect would have avoided. This is the basic lesson of the liberal tradition of limited government: a state that treats its citizen as a respect-worthy stranger is likely to be more attractive than one that sees the citizen as a beloved child or lover. Lovers take liberties that states should not. ${ }^{81}$

Accordingly, I hear both my traditions--the Jewish law sentiment that punishment is for God, not men, and the liberal suspicion of totalistic states that is both a reading of the biblical prophets' critique of the kings and a rejection of

${ }^{76}$ Compare Exodus 12:29 (describing mixed multitude that went up from Egypt together with children of Israel), with PLATO, MENEXENUS 237-38 (R.G. Bury trans., 1966) (describing traditional Athenian belief that first Athenians sprang from ground of Athens).

${ }^{77}$ See supra note 2 .

${ }^{78}$ See 2 KARL R. POPPER, THE OPEN SOCIETY AND ITS ENEMIES 232-40 (1963).

${ }^{79}$ Braithwaite, supra note 1 , at 25.

${ }^{80}$ HOBBES, supra note 49 , at 223,388 ; Cover, supra note 6 , at $60-68$.

${ }^{81}$ See Greenwood, supra note 40 , at 801,807 n.62 (arguing that equality principles often are inappropriate (inadequate) among friends). 
their aspirations to messianic redemption-urging us to tread lightly. Those who wish to have the state play God-by taking life or destroying it--are treading where angels should fear to walk. Those who wish to have the state play church - by forcing reconciliation and reform-may also be passing beyond the limits of a decent democracy.

The basic premise of restorative justice seems completely sound. If the goal is to reduce crime, harsh punishment alone seems unlikely to work. You cannot teach a child to avoid hitting others by hitting him; it is hard to believe that you can teach a people to not kill by killing, or teach criminals to respect the law and rights of others by violating the rights of the accused, or teach them to get a job by making them unemployable. Axes of Evil notwithstanding, most evil is done by people who are enmeshed in a system that invites them to do it; ${ }^{82}$ one taskof thinkers about criminal law is to understand why and how. Bringing criminals and potential criminals back into the web of constraints that is a functioning society is precisely the track that seems likely to work for the legitimate function of criminal law: to reduce crime.

\footnotetext{
${ }^{82} \mathrm{Or}$, in the case of murder, by people who have simply lost their tempers. Making fatal weapons less readily available would give them time to calm down. This, not some higher quality of humanity, more effective deterrence, or even lower levels of anger or alienation, strikes me as the main reason for Great Britain's lower murder rates (in a society that seems generally less law abiding and more violent than our own, at least if soccer games are any indication).

The homicide rate in England and Wales has almost doubled in the last thirty years and stood at 14.4 homicides per million people as of 2000-01. HOME OFFICE, CRIMINAL STATISTICS ENGLAND AND WALES 2000, at 78 tbl.4.1 [hereinafter ENGLAND AND WALES STATISTICS], available at $\mathrm{http}: / / \mathrm{www}$.archive.official-documents.co.uk/document $/ \mathrm{cm} 53 / 5312 / \mathrm{cm} 5312 . \mathrm{htm}$ (adjusted to exclude fifty-eight Chinese nationals who collectively suffocated in lorry en route to Britain). In comparison, the United States murder and non-negligent homicide rate for 2000 was three to four times higher: 55 homicides per million people, dramatically down from 94 per million in 1990 . UNIFORM CRIME REPORTS, OCT. 22, 2001, at 14. The United States definition appears to be somewhat narrower, so the true difference may be greater than the statistics suggest.

In sharp contrast to this dramatic difference in homicide rates, overall violent crime rates in the two countries appear to be fairly similar. England and Wales had overall violent crime rates in the range of 4,940-5,740 per million in the early 1990s until a change in offense coverage raised the rate to 11,600-13,920 from 1998-99 through 2000-01. ENGLAND AND WALES STATISTICS, supra, at 40 tbl.2.3. In comparison, the United States rate ranged from 5,247-7,581 per million during that period. U.S. CENSUS BUREAU, STATISTICAL ABSTRACT OF THE UNITED STATES: 2001, at $182 \mathrm{tbl} .291$, available at http://www.census.gov/prod/www/statistical-abstract-us.html. The dramatic change in the English rate due to a change in collection method suggests that the differences between the United States and England rates of overall violent crime are not meaningful although the trend lines-crime increasing in England and decreasing in the United States-more likely are.
} 